\title{
Expression of Pax6 and Pax7 Proteins During the Central Nervous System Development in Human Embryos
}

\author{
Expresión de Proteínas Pax6 y Pax7 Durante el Desarrollo \\ del Sistema Central Nervioso en Embriones Humanos
}

Aimar Namm ${ }^{1,2}$; Andres Arend ${ }^{1}$; Siim Suutre ${ }^{1} \&$ Marina Aunapuu ${ }^{1,2}$

NAMM, A.; AREND, A.; SUUTRE, S. \& AUNAPUU, M. Expression of Pax6 and Pax7 proteins during the central nervous system development in human embryos. Int. J. Morphol., 38(2):259-264, 2020.

SUMMARY: The family of paired box (Pax) genes encodes the transcription factors that have been emphasized for the particular importance to embryonic development of the CNS, with the evidence obtained from various animal models. Human embryos have rarely been available for the detection of the expression of Pax family members. In this study 32 human embryos of Carnegie (CS) stages 10-20 were investigated to find the differences in the expression of Pax6 and Pax 7 proteins in different regions of the neural tube and the caudal spinal cord. The expression of Pax 6 and Pax7, as determined by immunohistochemistry, showed a tendency to increase in the later stages of the development both in the spinal cord and the brain. Significantly weaker expression of Pax6 and Pax7 was observed at CS 10 as compared to the later stages. At CS 10-12 weak expression of Pax6 was noticed in both dorsal and ventral parts of the developing spinal cord, while the expression of Pax7 was restricted to the cells in the roof plate and the dorsal part of the spinal cord. At CS 14-20 in the developing spinal cord Pax6 and Pax7 were detected mostly in the neuroepithelial cells of the ventricular layer, while only weak expression characterized the mantle and the marginal layers. At the same stages in the developing brain Pax6 and Pax 7 were expressed in the different regions of the forebrain, the midbrain and the hindbrain suggesting for their involvement in the differentiation of neurons in specific parts of the developing brain.

KEY WORDS: Human embryos; Pax6 and Pax7; Developing spinal cord and brain.

\section{INTRODUCTION}

Pax6 and Pax7 are members of the family of transcriptional factors. Pax genes are defined by the presence of a paired box domain and a partial or complete homeobox domain (Breitling \& Gerber, 2000; Thompson \& Ziman, 2011). It is generally accepted that Pax genes are very important in the mammalian embryogenesis, especially in the formation and differentiation of various tissues (Dahl et al., 1997; Chi \& Epstein, 2002). Several studies have exhibited the temporally and spatially defined expression of the Pax genes in the formation of the nerve tissue, stressing their pivotal role in the early stage of the brain development (Kawakami et al., 1997; Osumi et al., 2008; Joven et al., 2013).

The forming of the dorsal-ventral axis of the developing neural tube begins during the secondary neurulation. Three different layers are formed in the wall of the neural tube: the inner ventricular layer of neuroepithelial cells, the middle mantle layer of neurons and the outer marginal layer of nerve fibres. During the further development the neurons of the mantle layer migrate and differentiate to the dorsal and ventral positions (Thompson \& Ziman). The importance of Pax6 and Pax7 for the formation of the dorsal-ventral part of the developing brain and in the spinal cord has been demonstrated by several studies on chick, frog, and mouse (Burrill et al., 1997; Osumi, 2001; Bandín et al., 2014). Terzic \& Saraga-Babic (1999) employing human embryos have found Pax6 to be involved in the brain regionalization and the establishment of dorsal-ventral polarity of the spinal cord. These studies have demonstrated that the overlapping expression of Pax6 and Pax7 subdivides the brain and the spinal cord along the dorsal-ventral axis, indicating the role of Pax genes in the developing central nervous system. The mutations, caused by the insufficient expression of Pax6 and Pax7, emphasize their

\footnotetext{
${ }^{1}$ Department of Anatomy, Institute of Biomedicine and Translational Medicine, University of Tartu, Ravila 19, 50411 Tartu, Estonia.

${ }^{2}$ Chair of Veterinary Bio and Population Medicine, Institute of Veterinary Medicine and Animal Sciences, Estonian University of Life Sciences, Kreutzwaldi 62, 51014 Tartu, Estonia.
} 
vital role in the differentiation of the neural tube (Thompson \& Ziman).

In the present study we aimed at the comparative determination of the temporal and spatial expression of Pax6 and Pax 7 protein during the early stages (Carnegie stages (CS) 10-20) of the spinal cord and brain development in human embryos.

\section{MATERIAL AND METHOD}

Obtaining embryos and section preparation. In this study 32 normal human embryos were examined. The embryos were classified according to Carnegie stages (CS). Human embryos of CS 10-20 (Table I) were obtained by medical abortions from Tartu University Hospital. The study was approved by the Ethics Review Committee on Human Research of the University of Tartu. The developmental stages and the number of embryos, which were used in this study, are described in Table I. The embryos were fixed in $4 \%$ paraformaldehyde and embedded in paraffin according to standard methods. The tissue blocks were serially cut in the transversal direction with microtome Ergostar HM-200 (Microm, Germany). In Figure 1 sub-parts of the developing brain are depicted together with a schematic representation of the process of cutting of embryos, resulting in $3 \mu \mathrm{m}$ thick transversally orientated slices.

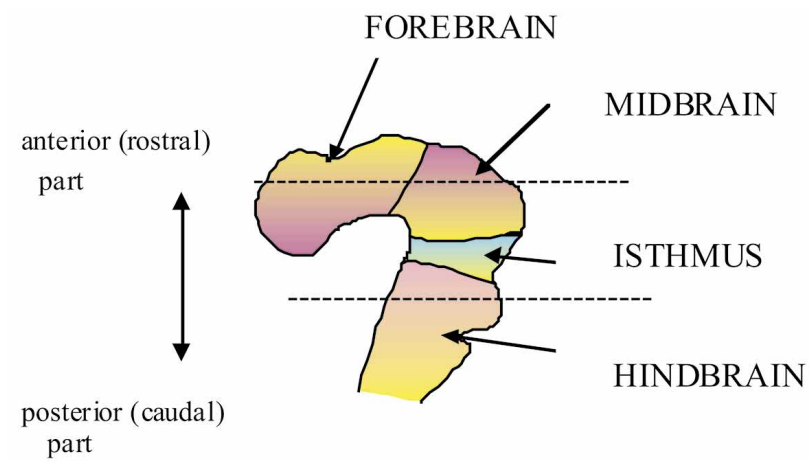

Fig. 1. Illustrative diagram of the sub-parts of the developing brain, dotted lines indicate the way of the process of cutting.

Table I. Number of studied embryos, developmental Carnegie stages, the age in postovulatory days, the crown-rump length and the plane of sections of investigated human embryos.

\begin{tabular}{llccl}
\hline Carnegie & Number of & Approx. days of & Crown-rump & Plane of \\
\hline stage & embryos & development & length, mm & section \\
\hline 10 & 3 & $22-23$ & $2-3.5$ & transversal \\
12 & 5 & $26-30$ & $3-5$ & transversal \\
14 & 6 & $31-35$ & $5-7$ & transversal \\
16 & 7 & $37-42$ & $8-11$ & transversal \\
18 & 7 & $44-48$ & $13-17$ & transversal \\
20 & 4 & $51-53$ & $18-22$ & transversal \\
\hline
\end{tabular}

Immunohistochemistry. The 3- $\mu$ m thick sections mounted on SuperFrost slides (Menzel-Gläser, Germany) were deparaffinised and rehydrated. Peroxidase activity was blocked by $0.6 \% \mathrm{H}_{2} \mathrm{O}_{2}$ (Merck, Darmstadt, Germany). The sections were washed in PBS ( $\mathrm{pH}=7.4$, Gibco, Invitrogen Corporation, USA) and then treated in $0.001 \mathrm{M}$ citrate buffer $(\mathrm{pH}=6.0)$ for 10 min using a Decloaking ChamberTM NxGen (Biocare, US) at $98-100{ }^{\circ} \mathrm{C}$. Non-specific protein binding was attenuated by incubation for $30 \mathrm{~min}$ at room temperature with normal $1.5 \%$ goat serum (Gibco, Invitrogen, USA). Slides were incubated with the primary antibodies Pax6 or Pax7 (Abcam, diluted 5 $\mathrm{mg} / \mathrm{ml}$ ) overnight at $4^{\circ} \mathrm{C}$ in a humidified chamber. On the next day the sections were incubated for $30 \mathrm{~min}$ at room temperature with universal secondary antibody (VECTASTAIN ABC Universal Kit, Burlingame, California, USA). Peroxidatic activity was detected with DAB (Vector, Burlingame, USA) applied for $5 \mathrm{~min}$ at room temperature. Then sections were rinsed, counterstained with hematoxylin, dehydrated and mounted with Eukitt (Fluka, Switzerland). Immunohistochemistry negative controls were performed by omitting the primary antibody.

Estimation of the expression of Pax6 and Pax7. Pax6 and Pax7 labelling was expressed by a subjective scale: $0=$ no immunostaining intensity, $1=$ weak immunostaining intensity, 2 = moderate immunostaining intensity and $3=$ strong immunostaining intensity. Three independent observers in a blinded fashion estimated the results of the study. The mean of estimations was calculated and used for statistical analysis. Data were analysed by the Kruskal-Wallis test (nonparametric analogue to ANOVA).

\section{RESULTS}

The semi-quantitative estimations of the expression of Pax6 and Pax7 proteins are summarized in Table II. The expression of Pax6 and Pax 7 proteins was detected in the developing spinal cord and the brain of human embryos at all studied stages of the development. However, variations seem to exist in the expression intensity at different developmental stages (Table II).

Expression of Pax6 and Pax7 in the developing spinal cord. Pax6 and Pax7 were found to be expressed at all stages in the developing spinal cord. At CS 10-12 the expression of Pax6 and Pax7 proteins was weak as compared to the later stages of the developing spinal cord. In addition, spatial differences in the expression of these proteins were seen in the early stages of the development as the dorsal-ventral boundary of the Pax6 expression was 
Table II. Expression of Pax6 and Pax7 in the developing spinal cord and the brain of the human embryos of CS 10-20. Expression intensity was graded as 0 (no staining), 1 (weak staining), 2 (moderate staining) or 3 (strong staining). The data are presented as the mean \pm SEM. Significant differences $(\mathrm{P}<0.05)$ in staining intensity between CS 10 groups and other CS groups of the same region are indicated with the same superscript letters.

\begin{tabular}{lcccccc}
\hline \multicolumn{1}{c}{ CS } & 10 & 12 & 14 & 16 & 18 & 20 \\
\hline Pax6 in spinal cord & $1.21 \pm 0.06 \mathrm{a},{ }^{\mathrm{b} . \mathrm{c}, \mathrm{d}}$ & $1.35 \pm 0.08$ & $1.60 \pm 0.05 \mathrm{a}$ & $1.75 \pm 0.07 \mathrm{~b}$ & $1.80 \pm 0.09 \mathrm{c}$ & $1.79 \pm 0.08 \mathrm{~d}$ \\
Pax6 in brain & $1.40 \pm 0.04 \mathrm{e}^{\mathrm{f}, \mathrm{g}, \mathrm{h}}$ & $1.65 \pm 0.06$ & $1.82 \pm 0.09 \mathrm{e}$ & $1.83 \pm 0.07 \mathrm{f}$ & $1.85 \pm 0.08 \mathrm{~g}$ & $1.83 \pm 0.08 \mathrm{~h}$ \\
Pax 7 in spinal cord & $1.15 \pm 0.07 \mathrm{i}^{\mathrm{j}, \mathrm{k}, 1}$ & $1.40 \pm 0.05$ & $1.62 \pm 0.11 \mathrm{i}$ & $1.70 \pm 0.07 \mathrm{j}$ & $1.72 \pm 0.06 \mathrm{k}$ & $1.74 \pm 0.051$ \\
Pax 7 in brain & $1.20 \pm 0.11 \mathrm{~m}^{\mathrm{m}, \mathrm{n}, \mathrm{p}}$ & $1.46 \pm 0.09$ & $1.70 \pm 0.05 \mathrm{~m}$ & $1.76 \pm 0.06 \mathrm{n}$ & $1.79 \pm 0.05 \mathrm{o}$ & $1.79 \pm 0.07 \mathrm{p}$ \\
\hline
\end{tabular}

very vague compared to that of Pax7. The expression of Pax6, although relatively weak, was noticed in both dorsal and ventral parts of the developing spinal cord at CS 10-12 (Fig. 2). At the same developmental stages the expression of Pax7 was restricted to the cells in the roof plate and the dorsal part of the spinal cord (Fig. 3). In the embryos of CS 14-20 strong

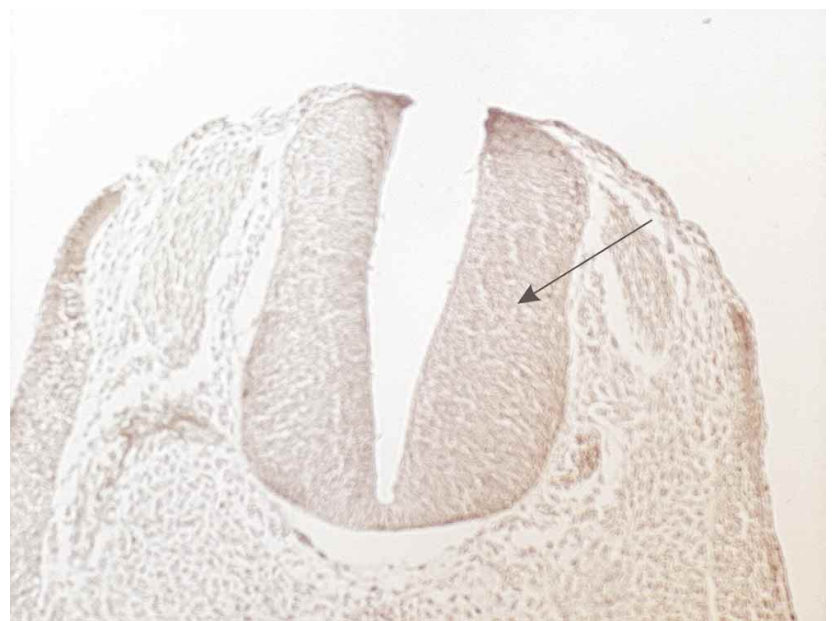

Fig. 2. Transversal section of the developing spinal cord in human embryo (DAB +hematoxyline $\mathrm{x} 100$ ) at CS 12, arrow indicate the expression of Pax6 in the wall of the developing spinal cord.

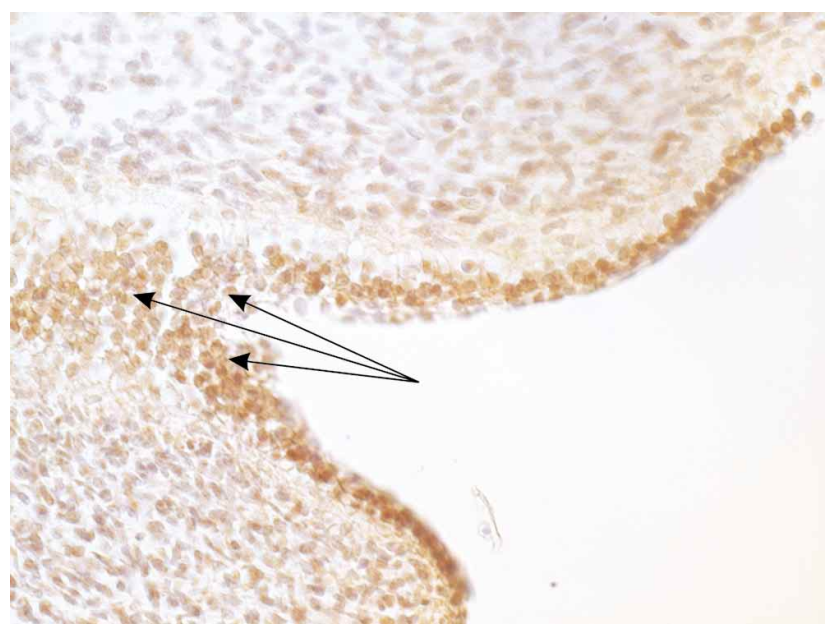

Fig. 3. Transversal section of the developing spinal cord in human embryo (DAB +hematoxyline $\mathrm{x} 400$ ) at CS 12 , arrows indicate the expression of $\operatorname{Pax} 7$ in the roof plate cells. expression of Pax6 and Pax7 was detected in the ventricular layer (Fig. 4), while weak expression characterized the mantle and the marginal layers of the developing spinal cord. In the embryos of CS 16-20 the strong expression of Pax6 and Pax7 was detected in the spinal ganglia (Fig. 5). At CS 16-20 the expression of $\operatorname{Pax} 7$ was seen in the non-neural

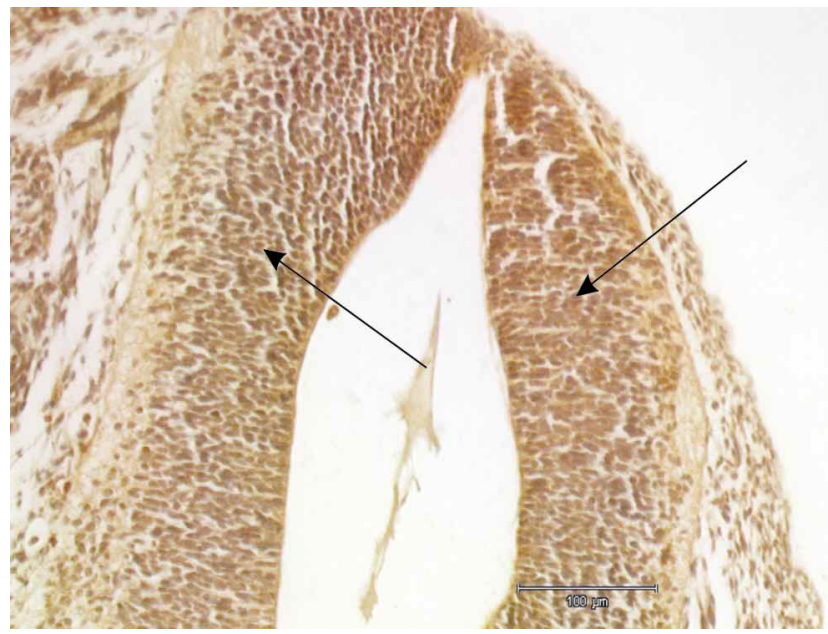

Fig. 4. Transversal section of the developing spinal cord in human embryo (DAB +hematoxyline $\mathrm{x} 200$ ) at CS 14, arrows indicate the expression of Pax6 in the ventricular layer.

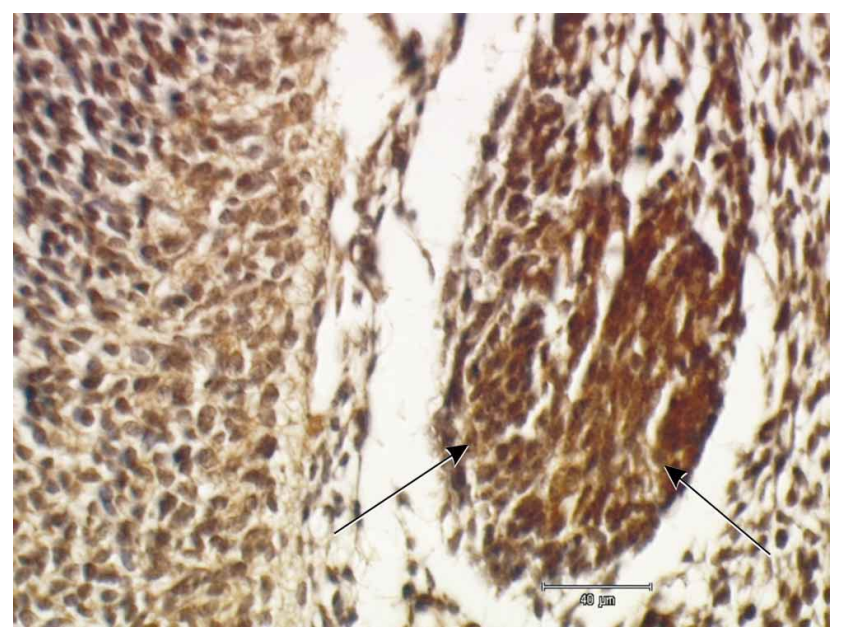

Fig. 5. Transversal section of the developing spinal ganglia in human embryo (DAB +hematoxyline $\mathrm{x} 400$ ) at CS 18, arrows indicate the expression of $\operatorname{Pax} 7$ in the spinal ganglia. 
ectoderm, but the signal of Pax6 was not detected in the non-neural ectoderm of the same embryos.

Expression of Pax6 and Pax7 in the developing brain. In the developing brain the expression of Pax6 and Pax7 was detected in all studied stages and in all samples. However, the results demonstrated variations in the expression intensity and localizations of examined proteins at different developmental stages (Table II). In the early stages of development Pax6 and Pax 7 were expressed in the ventricular layer of the forming neural tube (Fig. 6), whereas in later stages their expressions were found in more specific areas of the developing brain, which are described below.

At CS 10-12 weak expression of Pax6 and Pax 7 was observed in the closed neural tube. The statistically weaker signal of these proteins was found in the embryos of CS 10

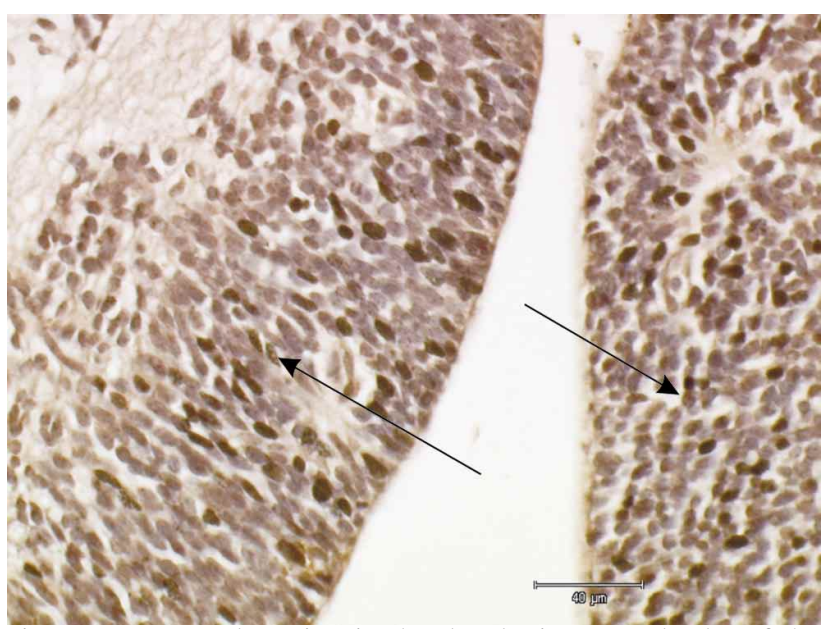

Fig. 6. Transversal section in the developing neural tube of the ventricular layer in the human embryo (DAB +hematoxyline $\mathrm{x} 400$ ) at CS 14, arrows indicate the expression of Pax6.

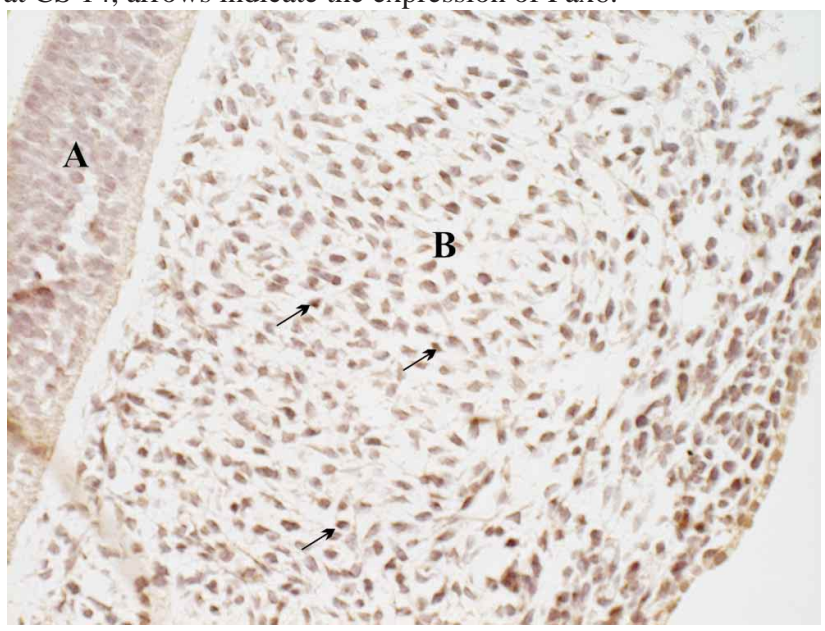

Fig. 7. Transversal section of the developing neural tube in the human embryo (DAB +hematoxyline $\mathrm{x} 400$ ) at CS 16, A ventricular layer, $\mathrm{B}$ - mantel layer, arrows indicate the expression of Pax6 in the mantel layer of the third ventricle. as compared to CS 14-20 (Table II). At CS 10-12, most of Pax6 and Pax7 signal was observed in the ventricular layer, where undifferentiated neuronal progenitor cells of the nervous system exist. At CS 14-16 strong expression of Pax6 was noticed in the ventricular layer and also in the mantel layer of the lateral, and in the third (Fig. 7) and the fourth ventricles of the developing brain. Pax7 demonstrated a similar signal pattern that was expressed in the ventricular layer, whereas the mantle and the marginal layer had definitely the weaker expression. At CS 18-20 moderate Pax6 expression was detected in the dorsal part of the telencephalon and diencephalon, as well as in the middleventral part of the myelencephalon (Fig. 8) and in the region of the isthmus. In the same embryos of CS 18-20 the expression of Pax7 was detected along the alar plate in the forming forebrain (Fig. 9). The signal of Pax7 was also observed in the ventral part of the mesencephalon.

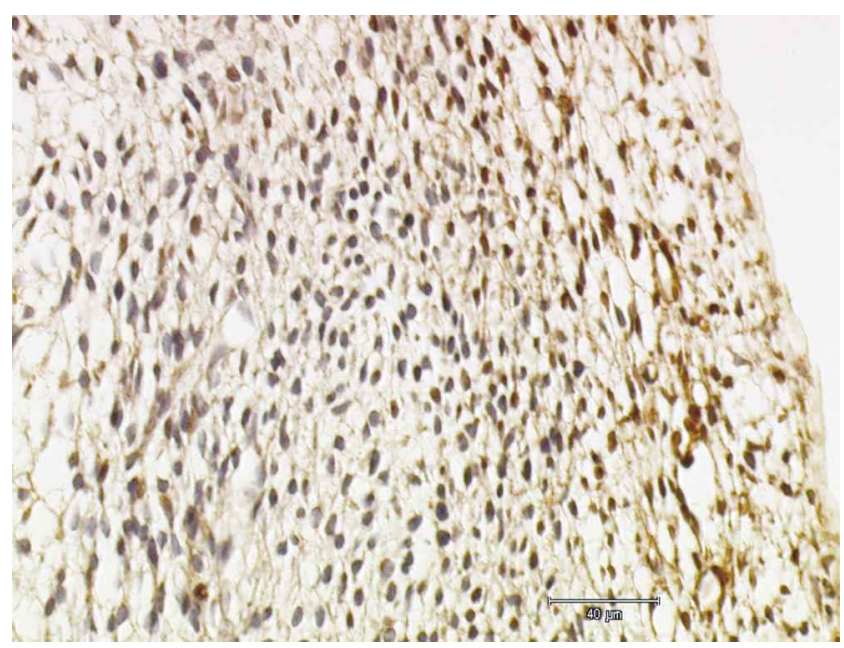

Fig. 8. Transversal section of the developing neural tube in the human embryo (DAB +hematoxyline $\mathrm{x} 400$ ) at CS 18 , expression of Pax6 in the wall of the middle part of the myelencephalon.

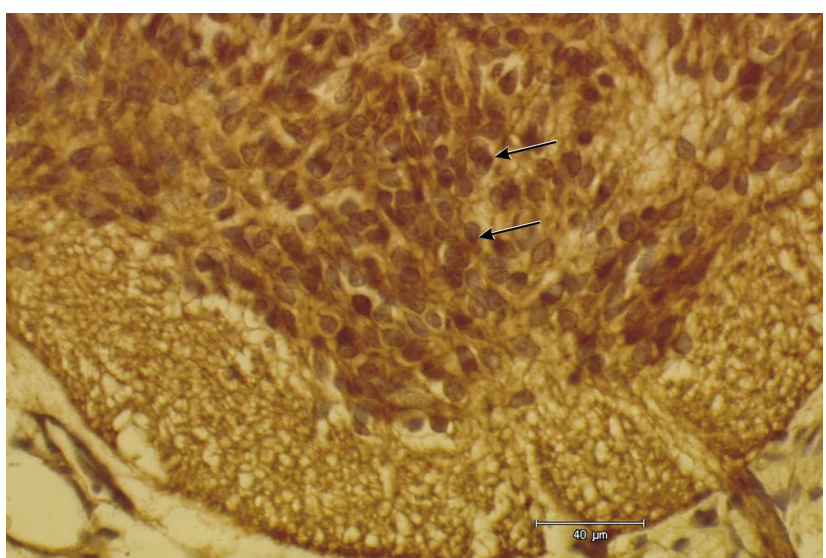

Fig. 9. Transversal section of the developing neural tube in the human embryo (DAB +hematoxyline x400) at CS 18, arrows indicate the expression of $\operatorname{Pax} 7$ in the forming neurons of the alar plate of the forebrain. 


\section{DISCUSSION}

In the present study the expression of Pax6 and Pax7 was detected in the developing nervous system of human embryos. The expression of Pax6 and Pax7 was observed at CS 10 (the earliest stage of the neural tube development studied), when the primordium of CNS consists entirely of proliferating neuroepithelial cells. At CS 10-12 mitotic activity of the progenitor cells gradually ceases and specific neurons differentiate according to their dorsal-ventral position, thus forming the definitive spinal cord (Terzic \& Saraga-Babic). The present study showed the relatively weak signalling intensity of Pax6 and Pax7 in the early developing stages of the forming spinal cord (Table II). It has been reported that notochord suppresses the expression of Pax3 (the member of the same family as Pax7) and Pax6 in the developing spinal cord (Goulding et al., 1993) and that Shh suppresses the expression of Pax6 in the ventral part of the neural tube (Ericson et al., 1997). One of the first steps in the spinal cord formation is the repression of Pax6, which allows the neuroepithelial cells to form the ventral part (Ericson et al.). Thus, the molecules that induce or repress the expression of Pax6 and Pax 7 may be responsible for the dorsal-ventral regional cell differentiation in the forming spinal cord (Kawakami et al.). In the present study at CS 14-20 Pax6 and Pax 7 were expressed in the mitotically active ventricular layer of the spinal cord, but relatively weak expression was noticed in the mantel and the marginal layers of the same embryos. This spatial signal intensity of Pax6 and Pax7 supports a model in which Pax proteins function in the ventricular layer of the spinal cord to induce the development of neuronal progenitor cells (Bel-Vialar et al., 2007; McHedlishvili et al., 2007; Osumi et al.).

The results of the present study suggest that Pax6 and Pax7 may have a role in the subdivision of the brain regions. In the early stages of the human brain development Pax6 and Pax7 were expressed in different regions similar to that seen in mouse and chicken embryos (Stoykova \& Gruss, 1994; Kawakami et al.). The signalling of Pax6 and Pax7 was detected in the ventricular layer of the brain vesicles. However, in the same embryos the expression of these proteins in the mantle and the marginal layers was not detected. In the later developmental stages of human embryos the expression of Pax6 and Pax7 was found in more specific regions of the brain. The expression of Pax6 was observed in the dorsal part of the forebrain and the middle-ventral part of the hindbrain, whereas the expression of Pax7 was noticed in the roof plate of the forebrain and the ventral part of the midbrain. Thus, the data confirmed the role of $\operatorname{Pax} 6$ and $\operatorname{Pax} 7$ in the differentiation of specific groups of neurons in the developing brain.

In summary, the expression pattern of Pax6 and Pax7 suggests that these proteins may have two different roles. In the early stages of development they could function in the regionalization and subdivision of the neural tube, but in the later stages $\operatorname{Pax} 6$ and $\operatorname{Pax} 7$ are involved in the differentiation of neurons in the specific parts of the brain.

\section{ACKNOWLEDGEMENTS}

The help of Dr. A. Sizarov in the process of collecting human embryos is greatly acknowledged. The study was partly funded by the targeted project No 0180012s11 of the Estonian Ministry of Education and Research.

NAMM, A.; AREND, A.; SUUTRE, S. \& AUNAPUU, M. Expresión de las proteínas Pax6 y Pax7 durante el desarrollo del sistema central nervioso en embriones humanos. Int. J. Morphol., $38(2): 259-264,2020$

RESUMEN: La familia de genes Pax del inglés (Paired box) codifica los factores de transcripción debido a la particular importancia en el desarrollo embrionario del SNC, con la evidencia obtenida de varios modelos animales. Rara vez han estado disponibles embriones humanos para la detección de la expresión de genes de la familia Pax. En este estudio, se investigaron $32 \mathrm{em}-$ briones humanos de Carnegie (CS) etapas 10-20 para encontrar las diferencias en la expresión de las proteínas Pax6 y Pax7 en diferentes regiones del tubo neural y la médula espinal caudal. La expresión de Pax6 y Pax7, según la inmunohistoquímica, se observó una tendencia a aumentar en las etapas posteriores del desarrollo, tanto en la médula espinal como en el cerebro. Se observó una expresión significativamente más débil de Pax6 y Pax7 en CS 10 en comparación con las etapas posteriores. En CS 10-12 se notó una expresión débil de Pax6 en las partes dorsal y ventral de la médula espinal en desarrollo, mientras que la expresión de Pax7 se limitó a células en la placa del techo y dorsal de la médula espinal. En CS 14-20 en la médula espinal en desarrollo, Pax6 y Pax7 se observó principalmente en las células neuroepiteliales de la capa ventricular, mientras que expresión débil se caracterizó en las capas marginales. En las mismas etapas en el cerebro en desarrollo, Pax6 y Pax 7 se expresaron en las diferentes áreas del prosencéfalo, el mesencéfalo y el mesencéfalo, lo que sugiere su participación en la diferenciación de las neuronas en partes específicas del cerebro en desarrollo.

PALABRAS CLAVE: Embriones humanos; Pax6 y Pax7; Desarrollo de la médula espinal y el cerebro. 


\section{REFERENCES}

Bandín, S.; Morona, R.; López, J. M.; Moreno, N. \& González, A. Immunohistochemical analysis of Pax6 and Pax7 expression in the CNS of adult Xenopus laevis. J. Chem. Neuroanat., 57-58:24-41, 2014.

Bel-Vialar, S.; Medevielle, F. \& Pituello, F. The on/off of Pax6 controls the tempo of neuronal differentiation in the developing spinal cord. Dev. Biol., 305(2):659-73, 2007.

Breitling, R. \& Gerber, J. K. Origin of the paired domain. Dev. Gen. Evol., 210(12):644-50, 2000.

Burrill, J. D.; Moran, L.; Goulding, M. D. \& Saueressing, H. PAX2 is expressed in multiple spinal cord interneurons, including a population of EN1+ interneurons that require PAX6 for their development. Development, 124(22):4493-503, 1997.

Chi, N. \& Epstein, J. A. Getting your Pax straight: Pax proteins in development and disease. Trends Genet., 18(1):41-7, 2002.

Dahl, E.; Koseki, H. \& Balling, R. Pax genes and organogenesis. Bioessays, 19(9):755-65, 1997.

Ericson, J.; Rashbass, P.; Schedl, A.; Brennen-Morton, S.; Kawakami, A.; van Heyningen, V.; Jessell, T. M. \& Briscoe, J. Pax6 controls progenitor cell identity and neuronal fate in response to graded Shh signalling. Cell, 90(1):169-80, 1997.

Goulding, M. D.; Lumsden, A. \& Gruss, P. Signals from the notochord and floor plate regulate the region-specific expression of two Pax genes in the developing spinal cord. Development, 117(3):1001-16, 1993.

Joven, A.; Morona, R.; González, A. \& Moreno, N. Spatiotemporal patterns of Pax3, Pax6, and Pax7 expression in the developing brain of Urodole Amphibian, Pleurodeles waltl. J. Comp. Neurol., 521(17):3913-53, 2013.

Kawakami, A.; Kimura-Kawakami, M.; Nomura, T. \& Fujisawa, H. Distributions of Pax6 and Pax7 proteins suggest their involvement in both early and late phases of chick brain development. Mech. Dev., 66(1-2):119-30, 1997.

McHedlishvili,L.; Epperlein, H. H.; Telzerow, A. \& Tanaka, E. M. A clonal analysis of neural progenitors during axolotl spinal cord regeneration reveals evidence for both spatially restricted and multipotent progenitors. Development, 134(11):2083-93, 2007.

Osumi, N. The role of Pax6 in brain patterning. Tohoku J. Exp. Med., 193(3):163-74, 2001.

Osumi, N.; Shinohara, H.; Numayama-Tsuruta, K. \& Maekawa, M. Pax6 transcription factor contributes to both embryonic and adult neurogenesis as a multifunctional regulator. Stem Cells, 26(7):1663$72,2008$.

Stoykova, A. \& Gruss, P. Roles of Pax-genes in developing and adult brain as suggested by expression patterns. J. Neurosci., 14(3 Pt. 2):1395412, 1994.

Terzic, I. \& Saraga-Babic, M. Expression pattern of Pax3 and Pax6 genes during human embryogenesis. Int. J. Dev. Biol., 43(6):501-8, 1999.

Thompson, J. A. \& Ziman, M. Pax genes during neural development and their potential role in neuroregeneration. Prog. Neurobiol., 95(3):334$51,2011$.

\author{
Corresponding author: \\ Aimar Namm \\ Department of Anatomy \\ Institute of Biomedicine and Translational Medicine \\ University of Tartu \\ Ravila 19, 50411 Tartu \\ ESTONIA
}

Email: aimar.namm@ut.ee

Received: 15-08-2019

Accepted: 13-09-2019 